\title{
GC-MS and Antibacterial Potential of Methanolic Extract Hyphaene Thebaica L. Fruit Pulp against Antibiotics-resistant Pathogens
}

\author{
Emad M. Abdallah ${ }^{1}\left(\mathbb{D}\right.$, Adil A.H. Mujawah² ${ }^{(D)}$ and Samiah H. Al-Mijalli3* (D) \\ ${ }^{1}$ Department of Science Laboratories, College of Science and Arts, Qassim University, Ar Rass, 51921 Saudi \\ Arabia. \\ ${ }^{2}$ Department of Chemistry, College of Science and Arts, Qassim University, Ar Rass, 51921 Saudi Arabia. \\ ${ }^{3}$ Department of Biology, College of Science, Princess Nourah bint Abdulrahman University, Riyadh, Saudi \\ Arabia.
}

\begin{abstract}
Methanol extract obtained from the fruits of Hyphaene thebaica (doum fruit) was chemically analyzed using GC-MS (gas chromatography-mass spectrometry). Up to thirty compounds were identified in the extract. Acetic acid decyl ester (36.80\%), n-Hexadecenoic acid (5.14\%),1H-Purine-2,6-dione, 3,7-dihydro1-methyl (4.24\%), 2-Furancarboxaldehyde, 5-(2-hydroxy-2-phenylacetyl)-dimethylhydrazone (4.67\%), Propanoic acid 3,3'-dithiobis (3.52\%) and [1,2,4] Triazolo[1,5-a]pyrimidin-7-ol were major components. The antibacterial potential of the extract against six clinical bacterial isolates resistant to antibiotics was also investigated, using various in vitro assays including well diffusion, minimal inhibitory and minimal bactericidal concentration. It was found that, the methanol extract of doum fruit was characterized by antibacterial action toward one Gram-positive ß-lactamase bacteria (Staphylococcus aureus), and one Gram-negative Multidrug-resistant bacteria (Proteus mirabilis). The other four bacterial strains showed no susceptibility towards the extract. The study suggests future additional biochemical and microbiological investigations in order to understand the mechanism of action of the bioactive molecules as antimicrobial agents.
\end{abstract}

Keywords: Bacteria, medicinal plants, biological activity, chemical composition, doum

\footnotetext{
*Correspondence: shalmejale@pnu.edu.sa

(Received: June 03, 2021; accepted: August 04, 2021)

Citation: Abdallah EM, Mujawah AAH, Al-Mijalli SH. GC-MS and Antibacterial Potential of Methanolic Extract Hyphaene Thebaica L. Fruit Pulp against Antibiotics-resistant Pathogens. J Pure Appl Microbiol. 2021;15(3):1655-1664. doi: 10.22207/JPAM.15.3.62

(C) The Author(s) 2021. Open Access. This article is distributed under the terms of the Creative Commons Attribution 4.0 International License which permits unrestricted use, sharing, distribution, and reproduction in any medium, provided you give appropriate credit to the original author(s) and the source, provide a link to the Creative Commons license, and indicate if changes were made.
} 


\section{INTRODUCTION}

Medicinal plants and their natural products were the main source for remedies since ancient time and continue to play this essential role until now, as it was estimated that, around 1981 and 2006, natural products accounted for $69 \%$ of new antibacterial agents ${ }^{1}$. Medicinal plants are a rich source of bioactive molecules. Saponines, Tannins, Alkaloids, Flavonoids, Alkenyl phenols, Glycoalkaloids, Phorbol, Sesquiterpenes Lactones, and Terpenoids are only a handful of some secondary metabolites with antimicrobial properties contained in medicinal plants ${ }^{2}$.

Throughout the ages, infectious diseases have been rated alongside wars and starvation as significant barriers to human development and survival. They continue to be one of the world's major causes of mortality. Moreover, in the midst of a steady stream of existing illnesses, epidemics of new and old infectious diseases erupt on a regular basis, massively exacerbating the global burden of infection ${ }^{3}$. As an example, a majority of the Gram-negative microbes, like Pseudomonas aeruginosa, Acinetobacter baumannii, and Enterobacteriaceae, are on the World Health Organization's (WHO) priority list of antibioticsresistant bacteria that considered the largest threat to human life ${ }^{4}$. Also, some Gram-negative genera are also have been recorded as health-threatening multiple resistant pathogens, like staphylococci, enterococci and pneumococci ${ }^{5}$. In this case, finding new antibiotics with different modalities of action and having low growth rates of resistance is a major global challenge. Antimicrobial resistance is expected to be the leading cause of death by 2050, but rapid success in the manufacture of modern antimicrobials will be crucial in combating them ${ }^{6}$. Accordingly, capacity of medicinal plants as promising antimicrobial agents is due to the many appealing characteristics of plants: they are easily available and inexpensive, plant extracts or compounds often show high-level efficacy against pathogens, and they seldom have serious side effects. The wide range of chemical structures found in plant-derived compounds can provide us with new antimicrobial mechanisms as well as new targets within the bacterial cell. Furthermore, the rapid advancement of new biotechnologies has paved the way for the production of bioactive compounds in an environmentally stable and lowtoxic manner? ${ }^{7}$.

Since Pharaonic culture (which included large regions of Egypt and Northern Sudan), the fruit pulp of the Doum-palm (Hyphaene thebaica L.) has been recognized for its medicinal benefits. The papyrus mentions Doum, and the tree appears in several tomb paintings. Sudan and Egypt are both familiar with the local name "Doum". Palms of doum are cultivated in the northern, southern, and western regions of Sudan ${ }^{8,9}$. Doum fruit has good nutritional and pharmaceutical properties, according to literature; it contains carbohydrates, fibers, essential minerals, some vitamins, and good amounts of phenolic compounds, all of which are important in controlling various physiological processes in the human body and protection against oxidation stresses, inflammations, microbes and cancer ${ }^{10,11}$. The present investigation aimed to determine the antibacterial potential of Doum-palm fruit (Hyphaene thebaica L.), against some clinical bacterial infections isolated from patients.

\section{MATERIALS AND METHODS \\ Sample collection}

The dry fruits of doum (Hyphaene thebaica) were collected from local markets in Khartoum, Sudan on June 2019. After identification by plant taxonomists (voucher specimen number: ALRASMEDP 48), the wooden husk of the fruit was rinsed with distilled water, carefully peeled and ground using grinding machine (Moulinex, France) to obtain a fine powder, and then stored in a dark glass bottle at $30-35^{\circ} \mathrm{C}$ until used.

\section{Microorganisms}

Five Gram-negative and one Grampositive clinical pathogenic Pseudomonas aeruginosa bacterial strains were obtained from Buraidah Central Hospital, Saudi Arabia. Identified samples were provided in Petri dishes anonymously (without any information about patients), by Dr. Shoumar Al-Shoumar (medical lab technician). The provided clinical bacteria and its sources were Pseudomonas aeruginosa (wound swab), Acinetobacter baumannii (Trachea aspiration), Klebsiella pneumonia (Trachea aspiration), Escherichia coli (urine), Proteus mirabilis (abscess) and Staphylococcus aureus 
(blood). Standard microbiological techniques were used to validate their morphological, cultural, and biochemical characteristics ${ }^{12}$.

\section{Preparation of methanolic extracts}

50 grams of the previously prepared powder of the doum fruit was macerated in 500 $\mathrm{mL}$ of $80 \%$ methanol (Merck KGaA, Germany) in a well-tighten dark container for up to 3 days in the incubator at $40^{\circ} \mathrm{C}$ with frequent shaking. After that, the solvent was totally eliminated under reduced pressure, leaving a residual free of methanol. The crude extract was isolated and reconstituted in $80 \%$ methanol and working extract was made at a concentration of $500 \mathrm{mg} / \mathrm{mL}$.

Gas chromatography-mass spectrometry (GC-MS)

Gas chromatograph (Shimadzu 2010 ultra plus, Japan) was coupled with Shimadzu Mass detector; GC was performed in the split less mode. Column $30.0 \times 0.25 \mathrm{~mm} \times 1 \mu \mathrm{m}$, under the following conditions: Carrier gas Helium ( He: $99.999 \%$ ) constant flow $1.6 \mathrm{~mL} / \mathrm{min}$; and initial entry temperature $50^{\circ} \mathrm{C}$ after a $18 \mathrm{~s}$ retard; injection volume, $1 \mu \mathrm{L}$ (LVI) liner velocity, oven temperature program, $50^{\circ} \mathrm{C} / \mathrm{min}$, hold time 4.00 min. Mass detector: Shimadzu 2010 ultra plus The MS tool transfer line temperature was $230^{\circ} \mathrm{C}$. MS Programmed the electron ionization situation with an ionization energy of $76 \mathrm{eV}$ was used: Library used: NIST Version-Year 2017, Mass scan (m/z): $30-450$, the total MS run time was 30 minutes. The constituents demonstrated by GC were identified by making a comparison between the MS values and the standard compounds reported in the National Institute of Standards and Technology library (NIST), using their retention on time and mass fragmentation patterns ${ }^{13,14}$.

\section{Antibiotics susceptibility assay}

The antibiotic susceptibility profile of the isolated clinical pathogenic bacterial strains was investigated following the assay mentioned in the Clinical and Laboratory Standards Institute's guidelines $(C L S I)^{15}$ and using the MicroScan WalkAway system (96 plus, Bekman Coulter, USA) in order to evaluate the possible susceptibility or resistance of the isolated clinical strains, antibiotics used are represented most regular antibiotics from different antibiotics generations, including Beta-lactam aztreonam, Penicillin, Ampicillin, Amikacin, Amoxicillin/clavulanic acid, Ampicillin/sulbactam, Cefepime, Trimethoprim/
Sulfamethoxazole, Ciprofloxacin, Gentamicin, Moxifloxacin, Piperacillin/tazobactam, and many more. Briefly, the referenced broth microdilution method ${ }^{15}$ has been applied, an overnight culture broth of bacterial isolates was modified to be equivalent to $0.5 \mathrm{McF}$ arland (BSS 0.5, Roth, Germany), the adjusted bacterial suspension was inoculated in the panel, and the desired antibiotics have been loaded as well. The seeded panel was incubated in the MicroScan WalkAway system, the incubation period is 24 hours for The Gram-positive and 8 hours for the Gram-negative bacteria, the MicroScan WalkAway system automatically read and expressed as resistant or sensitive to the antibiotics. The sheets of the automated results have been collected from the machine, which showed the susceptibility of microorganisms to antibiotics.

\section{Agar diffusion method}

The antibacterial efficacy of Doum fruits methanol extract against the clinical strains was evaluated using an agar well diffusion assay ${ }^{16}$. Plates containing Nutrient agar (NutriSelect ${ }^{\circledR}$ Plus, Merck, USA) was made by pouring $25 \mathrm{~mL}$ of autoclaved medium into sterile plates $(90$ $\mathrm{mm}$ in diameter) and left for up to 15 minutes until solidified at room temperature. Pathogenic strains were then spread through the agar medium with sterilized cotton swab. Then, with the aid of a sterile cork-borer, three wells were drilled separately on each plate $(6 \mathrm{~mm}$ in diameter) and $100 \mu \mathrm{l}$ of the working extract of doum $(500 \mathrm{mg} /$ $\mathrm{mL}$ ) was placed in two wells, and $100 \mu \mathrm{l}$ of the referenced antibacterial drug, Chloramphenicol $2.5 \mathrm{mg} / \mathrm{mL}$ (Alcon, USA), was placed in the third well. Forthwith, seeded plates were cautiously transferred to an incubator at $35^{\circ} \mathrm{C}$ for up to 24 hours. The antibacterial efficacy of the working extract was recorded by measuring the clear inhibition zone around the incubated wells in millimeters $(\mathrm{mm})$.

\section{Determination of the minimal inhibitory concentration (MIC)}

The clinical isolates that showed remarkable susceptibility to the working doum extract with the agar diffusion test were investigated for the minimal inhibitory concentration (MIC) using the dilution method ${ }^{17}$, with minor modifications. Descending concentrations of the extract at $250,125,62.5,31.25$, and $15.62 \mathrm{mg} / \mathrm{mL}$ 
were set using a two-fold serial dilution method. To another group of tubes containing $1.0 \mathrm{~mL}$ of nutrient broth that was previously autoclaved, additional $1.0 \mathrm{~mL}$ of serially diluted extracts were loaded and $100 \mu$ l of the bacterial suspension were also added to each tube. As a negative control, to another nutrient broth tube, $1.0 \mathrm{~mL}$ of absolute $(99.8 \%)$ methanol was filled instead of the tested plant extract. A positive control tube was also prepared by adding $100 \mu \mathrm{l}$ to a tube containing only nutrient broth. These tubes were covered and incubated overnight at $35^{\circ} \mathrm{C}$. all tubes were visually inspected for possible bacterial growth by examining the development of turbidity on the incubated test tubes similar to the control tube. The MIC was described as the lowest dilution of the plant extract that did not result in noticeable growth.

Determination of the minimal bactericidal concentration (MBC)

The minimum bactericidal concentration (MBC) of the Doum fruits methanol extract against the clinical bacterial isolates were determined following the assay reported by Doughari and Manzara $^{18}$, with minor changes. $100 \mu$ of each of the tubes resulted from the MIC test which showed no visible growth was dropped above the surface of the Mueller Hinton agar (NutriSelect ${ }^{\circledR}$ Plus, Merck, USA) plates, and then incubated for up to 24 hours at $35-37^{\circ} \mathrm{C}$. After incubation period, plates were inspected for bacterial growth. The MBC value was described as the lowest concentration that resulted in no single bacterial colony on the Mueller Hinton agar plate.

\section{RESULTS AND DISCUSSION}

Results of the Gas chromatographymass spectrometry (GC-MS) spectrum are shown in (Table 1). The NIST database was used to interpret the mass spectrum (GC-MS). The unknown constituent's spectrum was compared to the spectrum of identified components in the NIST library. Results showed that, Doum methanol extract includes some active principles, its composition along with their structure and percentage, retention time, molecular formula and molecular weight are represented in (Table 1). The GC-MS analysis identified 30 compounds revealed that the extract was found to be a complex mixture of various chemicals, the highest chemical composition of Hyphaene thebaica (doom) methanol extract was Acetic acid decyl ester with (36.80\%) followed by $\mathrm{n}$-Hexadecenoic acid (5.14\%),1H-Purine-2,6-dione, 3,7-Dihydro1-methyl (4.24\%), 2-Furancarboxaldehyde, 5-(2-Hydroxy-2-phenylacetyl), Dimethylhydrazone (4.67\%), Propanoic acid, 3,3'-Dithiobis (3.52\%) and $[1,2,4]$ Triazolo [1,5-a] pyrimidin-7-ol (3.01\%) respectively. Other compounds were in trace quantities (Table 1 and Fig. 1). Previous studies revealed that compounds isolated from doum are solvent-dependent, the essential oils of doum reported up to 57 compounds by GC-MS, including Incensole acetate (19.81\%), Incensole (17.52\%), Limonene (2.42\%), Beta-pinene (1.98\%), $\alpha$-Terpineol (0.95\%), Terpinen 4-ol $(1.77 \%)$, Sabinene $(0.82 \%)$, and many more ${ }^{19}$. Moreover, Doum fruit possesses good functional properties, as it is rich in fibers, minerals, vitamins
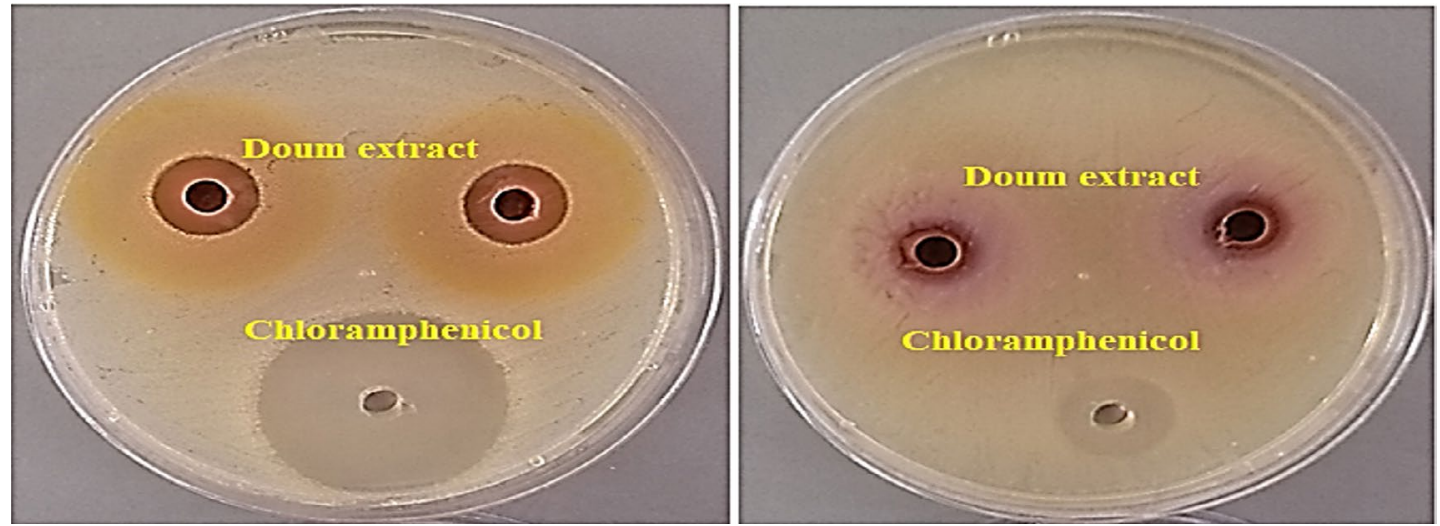

Fig. 1. Representative photo of positive antibacterial efficacy of methanolic extract of doum fruit against two clinical isolates

Journal of Pure and Applied Microbiology 
Abdallah et al. | J Pure Appl Microbiol | 15(3):1655-1664 | September 2021 | https://doi.org/10.22207/JPAM.15.3.62

Table 1. GC-MS analysis report for the methanol extract of Hyphaene thebaica (Doum) fruits

\begin{tabular}{|c|c|c|c|c|c|}
\hline $\begin{array}{l}\text { Retention } \\
\text { time }\end{array}$ & Compound & $\begin{array}{l}\text { Molecular } \\
\text { Weight }(\mathrm{g} / \mathrm{mol})\end{array}$ & $\begin{array}{l}\text { Molecular } \\
\text { formula }\end{array}$ & $\begin{array}{l}\text { Chemical } \\
\text { structure }\end{array}$ & $\begin{array}{c}\text { Percentage } \\
(\%)\end{array}$ \\
\hline 4.158 & Acetic acid decyl ester & 200.32 & $\mathrm{C}_{12} \mathrm{H}_{24} \mathrm{O}_{2}$ & & 36.8 \\
\hline 8.352 & Tridecane & 184.36 & $\mathrm{C}_{13} \mathrm{H}_{28}$ & & 1 \\
\hline 9.311 & $\begin{array}{l}\text { 4H-Pyran-4-one, 2,3-dihydro- } \\
\text { 3,5-dihydroxy-6-methyl }\end{array}$ & 144.12 & $\mathrm{C}_{6} \mathrm{H}_{8} \mathrm{O}_{4}$ & & 0.72 \\
\hline 10.609 & $\begin{array}{l}\text { 2-furan-carboxaldehyde, 5- } \\
\text { (2-hydroxy-2-phenylacetyl)-, } \\
\text { dimethylhydrazone }\end{array}$ & 272.3 & $\mathrm{C}_{15} \mathrm{H}_{16} \mathrm{~N}_{2} \mathrm{O}_{3}$ & & 4.67 \\
\hline 11.445 & Thymol & 150.22 & $\mathrm{C}_{10} \mathrm{H}_{14} \mathrm{O}$ & & 1.45 \\
\hline 11.801 & 2-Propen-1-ol, 3-phenyl- & 134.17 & $\mathrm{C}_{9} \mathrm{H}_{10} \mathrm{O}$ & & 0.96 \\
\hline 12.694 & Orcinol & 124.14 & $\mathrm{C}_{7} \mathrm{H}_{8} \mathrm{O}_{2}$ & & 4.68 \\
\hline 15.358 & Diethyl phthalate & 222.24 & $\mathrm{C}_{12} \mathrm{H}_{14} \mathrm{O}_{4}$ & & 0.6 \\
\hline 16.24 & $\begin{array}{l}\text { 2-sec-butyl-4,6-dinitrophenyl } \\
\text { 3-methylbut-2-enoate }\end{array}$ & 322 & $\mathrm{C}_{15} \mathrm{H}_{18} \mathrm{~N}_{2} \mathrm{O}_{6}$ & & 1.53 \\
\hline
\end{tabular}




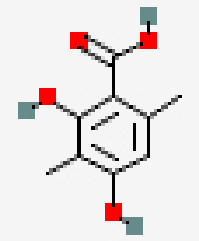

0.64

$\mathrm{C}_{5} \mathrm{H}_{4} \mathrm{~N}_{4} \mathrm{O}$

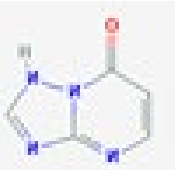

3.01 7-ol

136.11

1,2

144.211 ethyl ester

166.13 3,7-dihydro-1-methyl

178.14 gamma-lactone

256.4241

$$
\mathrm{C}_{16} \mathrm{H}_{32} \mathrm{O}_{2}
$$<smiles>C=CCCC(=O)CCC(C)C</smiles>

1.44

$\mathrm{C}_{8} \mathrm{H}_{16} \mathrm{O}_{2}$

$\mathrm{C}_{6} \mathrm{H}_{6} \mathrm{~N}_{4} \mathrm{O}_{2}$<smiles>Cn1c(=O)[nH]c2nc[nH]c2c1=O</smiles>

4.24

$\mathrm{C}_{10} \mathrm{H}_{18} \mathrm{O}$

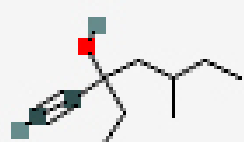

20.15 Tributyl acetylcitrate

402.5

$\mathrm{C}_{20} \mathrm{H}_{34} \mathrm{O}_{8}$

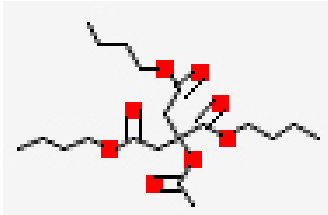

$\mathrm{C}_{19} \mathrm{H}_{34} \mathrm{O}_{2}$

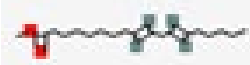

1.49 ester, 


$$
\mathrm{C}_{6} \mathrm{H}_{10} \mathrm{O}_{4} \mathrm{~S}_{2}
$$

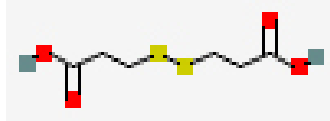

$$
\mathrm{C}_{11} \mathrm{H}_{20} \mathrm{O}_{2}
$$<smiles>O=C1CCCCCCCCCCC1</smiles>

$$
\mathrm{C}_{24} \mathrm{H}_{48}
$$

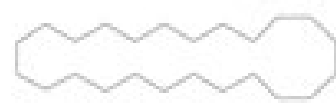

$$
\mathrm{C}_{5} \mathrm{H}_{8} \mathrm{O}_{2}
$$<smiles>C=C(C)C(C)=C(C)C</smiles>

$\mathrm{C}_{24} \mathrm{H}_{38} \mathrm{O}_{4}$

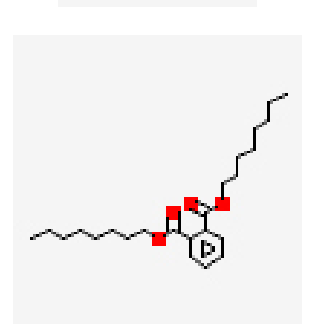

animals, and even aquaculture fish, resulted to super or multi-drug resistant pathogens. The aggregation of genes in bacteria is a common cause of this phenomena ${ }^{21}$. Therefore, the search for new sources of antibacterial drugs is of great

\begin{tabular}{|c|c|c|}
\hline Clinical isolate & Source & Resistant to: \\
\hline Pseudomonas aeruginosa & Wound swab & Aztreonam, piperacillin/tazobactam \\
\hline Acinetobacter baumannii & Trachea aspiration & $\begin{array}{l}\text { Amikacin, cefepime, cefoxitin, ciprofloxacin, gentamicin, } \\
\text { imipenem, levofloxacin, meropenem, tobramycin, Trimethoprim } \\
\text { / Sulfamethoxazole, and many more. }\end{array}$ \\
\hline Klebsiella pneumonia & Trachea aspiration & $\begin{array}{l}\text { Amikacin, amoxicillin / Clavulanic acid, ampicillin/sulbactam, } \\
\text { aztreonam, cefepime, ciprofloxacin, gentamicin, moxifloxacin, } \\
\text { and many more }\end{array}$ \\
\hline Escherichia coli & Urine & Ciprofloxacin, tigecycline, aztreonam, and levofloxacin \\
\hline Proteus mirabilis & Abscess & $\begin{array}{l}\text { Amoxicillin / Clavulanic acid, gentamicin, Ampicillin/sulbactam, } \\
\text { tobramycin, ampicillin, and trimethoprim / Sulfamethoxazole. }\end{array}$ \\
\hline Staphylococcus aureus & Blood & Beta-lactamase positive, Penicillin, Ampicillin \\
\hline
\end{tabular}
importance. The results of the antibacterial evaluation revealed that doum methanol extract

Table 2. The antibiotics susceptibility profile of the clinical bacterial strains 
Table 3. The antibacterial potential of the methanolic extract of doum fruit

\begin{tabular}{|c|c|c|c|c|c|c|}
\hline \multirow[t]{3}{*}{ Compound } & \multicolumn{6}{|c|}{ Mean of inhibition zone $(\mathrm{mm})^{*}$} \\
\hline & \multicolumn{5}{|c|}{ Gram-negative } & \multirow{2}{*}{$\begin{array}{c}\text { Gram-positive } \\
\text { Sa }\end{array}$} \\
\hline & $\mathrm{Pa}$ & $\mathrm{Kp}$ & Ec & $\mathrm{Pm}$ & $\overline{\mathrm{Ab}}$ & \\
\hline $\begin{array}{l}\text { Doum methanol extract } \\
(500 \mathrm{mg} / \mathrm{mL})\end{array}$ & 6.00 & 6.00 & 6.00 & 10.25 & 6.00 & 14.50 \\
\hline $\begin{array}{l}\text { Chloramphenicol } \\
(5 \mathrm{mg} / \mathrm{mL})\end{array}$ & 15.00 & 9.00 & 30.00 & 14.00 & 29.00 & 33.00 \\
\hline
\end{tabular}

*Pa=Pseudomonas aeruginosa, $\mathrm{Ec}=$ Escherichia coli, $\mathrm{Kp}=$ Klebsiella pneumonia, $\mathrm{Pm}=$ Proteus mirabilis, Ab=Acinetobacter baumannii, Sa= Staphylococcus aureus. $6.0 \mathrm{~mm}=$ No activity (diameter of the well).

Table 4. MIC and MBC of the susceptible bacteria to doum methanolic extracts

\begin{tabular}{|c|c|c|}
\hline Bacterial strain & $\begin{array}{c}\mathrm{MIC} \\
(\mathrm{mg} / \mathrm{mL})\end{array}$ & $\begin{array}{c}\mathrm{MBC} \\
(\mathrm{mg} / \mathrm{mL})\end{array}$ \\
\hline Staphylococcus aureus & 31.25 & 31.25 \\
\hline Proteus mirabilis & 250.00 & 125.00 \\
\hline
\end{tabular}

was effective in inhibiting the growth of two antibiotics resistant bacteria and non-effective against the other four pathogens. As shown in (Table 3), the zone of inhibition (measured in $\mathrm{mm}$ ) is a circular region surrounding the checked extract's spot where bacteria colonies do not grow. This region of inhibition was used to determine the bacteria's susceptibility to the extract or antibiotic (Fig. 1), the most susceptible bacteria were the beta-lactamase Staphylococcus aureus $(14.5 \mathrm{~mm})$ and Proteus mirabilis $(10.25 \mathrm{~mm})$, respectively. These results were confirmed by MIC and MBC tests (Table 4), were Staphylococcus aureus recorded $31.25 \mathrm{mg} / \mathrm{mL}$ for $\mathrm{MIC}$ and $\mathrm{MBC}$, and Proteus mirabilis recorded $250 \mathrm{mg} / \mathrm{mL}$ MIC and $125 \mathrm{mg} / \mathrm{mL} \mathrm{MBC}$. Accordingly, this finding of this study recommend the Sudanese doum for treatment of Staphylococcus aureus infections. This bacterium is a causative agent for various human infections such as bacteremia, infective endocarditis, osteoarticular, pleuropulmonary, and skin and soft tissue infections ${ }^{22}$. Our previous study showed that doum extract was active against an American type culture collection strain of Staphylococcus aureus (ATCC BAA 1026), where recorded $16.0 \mathrm{~mm}$ inhibition zone and
62.5 MIC. Meaning that, this beta-lactamase Staphylococcus aureus is much susceptible to the doum methanolic extract. Also, many previous studies reported remarkable antibacterial efficacy of different extracts of doum fruit, the activity includes both of the Gram-positive and Gramnegative microorganisms ${ }^{23-25}$. In particular, the antibacterial efficacy against the tested Grampositive bacteria is due to the presence of biologically active ingredients doum methanolic extracts. Other solvent extracts of doum fruit are suggested to be investigated for its antibacterial potential which could lead to understand the nature and mechanism of the bioactive molecules of this desert fruit. Finally, the findings of this investigation are supported by Similar previous studies; the $n$-hexane extract of Doum fruit showed remarkable antibacterial activity against intestinal microflora and potential constipation associated pathogens, whereas the aqueous extract showed moderate activity ${ }^{26}$. Similar study on the GC-MS of Sudanese Doum revealed up to 30 compounds from the aqueous solution of doum powder, including Tris (hydroxymethyl) nitromethane, 3-o-methyl-D-glucose, 5-Hydroxymethylfurfural, dl-Glyceraldehde dimer and Maltol ${ }^{27}$. Accordingly, the bioactive extracts of Doum fruit depend greatly on the type of solvent, either hydrophobic or hydrophilic.

\section{ACKNOWLEDGMENTS}

We would like to thank our colleagues for encouragement. Special thanks to Dr. Shoumar Abdulaziz Al-Shoumar (Buraidah Central Hospital) for providing clinical bacterial strains. 


\section{CONFLICT OF INTEREST}

The authors declare that there is no conflict of interest.

\section{AUTHORS' CONTRIBUTION}

All authors listed have made a substantial, direct and intellectual contribution to the work, and approved it for publication.

\section{FUNDING}

None.

\section{DATA AVAILABILITY}

All datasets generated or analyzed during this study are included in the manuscript

\section{ETHICS STATEMENT}

This article does not contain any studies with human participants or animals performed by any of the authors. Clinical bacterial isolates were provided from the hospital anonymously (No data from patients).

\section{REFERENCES}

1. Belkacem N, Khettal B, Hudaib M, Bustanji Y, AbuIrmaileh B, Amrine CSM. Antioxidant, antibacterial, and cytotoxic activities of Cedrus atlantica organic extracts and essential oil. Eur J Integr Med. 2021;42:101292. doi: 10.1016/j.eujim.2021.101292

2. Abdallah EM. Plants: An alternative source for antimicrobials. Journal of Applied Pharmaceutical Science. 2011;1(6):16-20.

3. Morens D, Folkers $G$, Fauci A. The challenge of emerging and re-emerging infectious diseases. Nature. 2004;430(6996):242-249. doi: 10.1038/nature02759

4. Maglangit F, Yu Y, Deng H. Bacterial pathogens: threat or treat (a review on bioactive natural products from bacterial pathogens). Nat Prod Rep. 2021;38:782-821. doi: 10.1039/dOnp00061b

5. Witte W, Cuny C, Klare I, Nubel U, Strommenger B, Werner G. Emergence and spread of antibioticresistant Gram-positive bacterial pathogens. Int J Med Microbiol. 2008;298(5-6):365-377. doi: 10.1016/j. ijmm.2007.10.005

6. Udaondo Z, Matilla MA. Mining for novel antibiotics in the age of antimicrobial resistance. Microbial Biotechnology. 2020;13(6):1702-1704. doi: 10.1111/1751-7915.13662

7. Gorlenko CL, Kiselev HY, Budanova EV, Zamyatnin-Jr AA, Ikryannikova LN. Plant Secondary Metabolites in the Battle of Drugs and Drug-Resistant Bacteria: New Heroes or Worse Clones of Antibiotics?. Antibiotics. 2020;9(4):170. doi: 10.3390/antibiotics9040170

8. Abdallah EM. Screening of Methanolic Extract for Antimicrobial Activity of Hyphaene thebaica L. Fruit Pulp from Sudanese Folklore. South Asian Journal of Research in Microbiology. 2021;9(1):6-12. doi: 10.9734/sajrm/2021/v9i130199

9. Ismail AAE, Mohamed SMM, EI-Weshahy MHA. Doumpalm in ancient Egypt. Journal of Association of Arab Universities for Tourism and Hospitality 2016;13(1):120. doi: 10.21608/jaauth.2016.49960

10. Faten MAE. Antioxidant and anticancer activities of doum fruit extract (Hyphaene thebaica). African Journal of Pure and Applied Chemistry. 2009;3(10):197201.

11. El-Beltagi HS, Mohamed HI, Yousef HN, Fawzi EM. Biological activities of the doum palm (Hyphaene thebaica L.) extract and its bioactive components. In: Shalaby E, Azzam M, editors. Antioxidants in foods and its applications, 1st ed. IntechOpen. 2018. doi: 10.5772/intechopen.74772

12. Holt JG, Krieg NR, Peter HAS, et al. Bergeys's Manual of Determinative Bacteriology, 9th edn. Baltimore, MD: Williams \& Wilkins. 1994.

13. Boriollo MFG, Marques MB, da Silva TA, et al. Antimicrobial potential, phytochemical profile, cytotoxic and genotoxic screening of Sedum praealtum A. DC. (balsam). BMC Complement Med Ther. 2020;20(1):133. doi: 10.1186/s12906-020-02915-6

14. Bicchi C, Brunelli C, Cordero C, Rubiolo P, Galli $M$, Sironi $A$. Direct resistively heated column gas chromatography (Ultrafast module-GC) for high-speed analysis of essential oils of differing complexities. J Chromatogr A. 2004;1024(1-2):195-207. doi: 10.1016/j.chroma.2003.10.018

15. CLSI (Clinical and Laboratory Standards Institute). Performance Standards forAntimicrobial Susceptibility Testing; 24th Informational Supplement. CLSIdocument M100-S24. Clinical and Laboratory Standards Institute, Wayne, PA. 2014.

16. Abdallah EM, Qureshi KA, Ali AMH, Elhassan GO. Evaluation of some biological properties of Saussurea costus crude root extract. Bioscince Biotechnology Research Communication. 2017;10(4):601-611. doi: $10.21786 / \mathrm{bbrc} / 10.4 / 2$

17. Abubakar EM. Antibacterial efficacy of stem bark extracts of Mangifera indica against some bacteria associated with respiratory tract infections. Scient Res Essay. 2009;4(10):1031-1037.

18. Doughari JH, Manzara S. In vitro antibacterial activity of crude leaf extracts of Mangifera indica Linn. Afr J Microbiol Res. 2008;2:67-72.

19. Ayoub NA, Eldahshan OA, Singab AB, Al-Azizi MM. Chemical Composition of Essential Oil from Doum Fruits Hyphaene thebaica (Palmae). Journal of Essential Oil Bearing Plants. 2011;14 (2):245-249. doi: 10.1080/0972060X.2011.10643928

20. Siddeeg A, Salih ZA, Al-Farga A, Ata-Elfadeel EMA, Ali AO. Physiochemical, Nutritional and Functional Properties of Doum (Hyphene thebaica) Powder and Its Application in Some Processed Food Products. Journal of Nutrition and Food Science Forecast. 2019;2(1):1009.

21. Hiroshi N. Multidrug resistance in bacteria. Ann Rev Biochem. 2009;78:119-146. doi: 10.1146/annurev. biochem.78.082907.145923 
22. Tong SY, Davis JS, Eichenberger E, Holland TL, Fowler Jr. VG. Staphylococcus aureus infections: epidemiology, pathophysiology, clinical manifestations, and management. Clin Microbiol Rev. 2015;28(3):603-661. doi: 10.1128/CMR.00134-14

23. Auwal MS, Mairiga IA, Shuaibu A, et al. Preliminary phytochemical and in vitro antibacterial evaluation of the crude pericarp extract of Hyphaene thebaica (doum palm). J Med Plant Herb Therap Res. 2013;1:1-7.

24. Abd-ELmageed SM, Abushady HM, Amin AA. Antibacterial and antioxidant activities of Physalis peruviana and Hyphaene thebaica extracts. African J Biol Sci. 2019;15(1):73-86. doi: 10.21608/ ajbs.2019.63997
25. Mohamed AA, Khalil AA, El-Beltagi HES. Antioxidant and antimicrobial properties of kaff Maryam (Anastatica hierochuntica) and doum palm (Hyphaene thebaica). Grasasya Ceites. 2010;61(1):67-75. doi: 10.3989/ gya.064509

26. Ewansiha JU, Ugo CE, Kolawole DI, Orji LS. Antibacterial Activities of Hyphaene thebaica (Doum Palm) Fruit Extracts against Intestinal Microflora and Potential Constipation Associated Pathogens in Yola Metropolis, Nigeria. Tanzania Journal of Science. 2021;47(1):104111.

27. Altayeb SOM. Chemical Characterization of Hyphaene thebaica Fruits by GC-MS and XRF Spectroscopy. MSc thesis. Sudan University of Science and Technology, Khartoum, Sudan. 2017. 